\title{
Gorove EszTER \\ Test, nyelv és énkonstrukciók Borbély Szilárd költészetében
}

Borbély Szilárd költői életművében nagy hangsúlyt kapott a test és nyelv kapcsolatának leírására tett kísérlet, $s$ ezen keresztül a rákérdezés az én helyére, szerepére, státuszára test és nyelv relációjában. Tanulmányom e kísérleteket vizsgálja a szerző két jelentős kötetében (Halotti Pompa; A Testhez), és egyúttal annak megmutatására is törekszik, hogy a gyász vagy a trauma tapasztalatai miként rendezik át - vagy kérdőjelezik meg - a test és a nyelv viszonyáról szóló elképzeléseket: hogyan tematizálhatók a gyász és a trauma vonatkozásában az énre irányuló kérdések. A nyelv és a test viszonya nem ragadható meg egyszerüen Borbély köteteiben, hiszen sem a színre vitt fogalmak, sem interakcióik nem kerülnek nyugvópontra, állandó mozgásuk figyelhető meg; egy olyan feszültségekkel teli reláció ez, amelyben az én helye is folyton megkérdőjeleződik. Ez pedig azért is kiemelkedően fontos a két kötet verseiben, mert személyes élmények kerülnek feldolgozásra bennük, vagyis (ön)életrajzi elemekkel dolgozó szövegekről beszélhetünk, legyen szó akár saját, akár átvett traumákról (női elbeszélők).

\section{A gyász hangjai: nyelv, test és én}

A Halotti Pompa elsődlegesen a gyász kötete, amely a költő szüleinek állít emléket, rögzítve a meggyilkolásuk körülményeit: ugyanakkor Borbély eltávolít a személyes eseménytől, s a tragédiát három nagy teológiai-mitológiai hagyományon (kereszténység, antik-római mitológia, haszidizmus) átszürve, a szekvencia müfaját mozgósítva dolgozza át közösségivé. A kötet mindegyik ciklusának címében szerepel ez a műfaji megjelölés: Nagyheti szekvenciák, Ámor \& Psziché szekvenciák, Haszid szekvenciák. A müfaji választást elemző szakirodalom a szekvenciának más-más aspektusát emeli ki: felmerül hasonlósága a szonettformához, az antistrófikus szerkesztés lehetősége, ${ }^{1}$ a modernség előtti énszemlélet felelevenítése, ${ }^{2}$ stb. Dolgozatom szempontjából talán a legfontosabb értelmezés a Dérczy Péteré és a Szűcs Terié, akik a szekvenciát olyan müfajként határozzák meg, amely a keresztény liturgikus zenei hagyományba ágyazódik, fő jellemzői pedig az ismétlés és a közösségi megszólaltatás.

\footnotetext{
${ }^{1}$ Márton László, Visszájára fordítani, Jelenkor, 2005/4, 390. http://www.jelenkor.net/archivum/cikk/759/ visszajara-forditani (Letöltés ideje: 2016. január 24.)

2 SzÉnÁsi Zoltán, Test, beszéd: Borbély Szilárd A Testhez címü kötetéröl, Alföld, 2011/6, 75-81.
} 
Ugyanakkor - bár a választott forma, motívum és sok esetben nyelvhasználat erösen a keresztény hagyományhoz kötődik - Borbély a kereszténység barokk hagyományozásában kitapintható világképpel éppen ellentétes belátásokig jut a Halotti Pompában. ${ }^{3}$ A szekvencia müfaján túl a három nagy hagyományhoz való kapcsolódás az átírások és újraértelmezések lehetőségeit kínálja: Borbély fogalmakat mozdít ki, értelmez át, felfüggeszti jelentéseiket. Ez a törekvés legerősebben a kötet első ciklusának, a Nagyheti Szekvenciáknak a sajátja, amelyben a feltámadás, az örökkévalóság, az élet és a halál közkeletű képzetei válnak bizonytalanná, saját maguk kifordításává. Krisztus feltámadása megkérdőjeleződik, a halál puszta halál lesz, folytatás és remény nélküli, jóllehet, a szövegek a halál visszavonhatatlanságát is elbizonytalanítják. E három fogalom - örökkévalóság, élet, halál - folyamatosan egymásra íródik, az „örök” sok esetben a végességgel asszociálódik, más esetekben viszont, a szó eredeti értelmében, a folytonosságot jelöli, vagy a halál véglegességének tényét kérdőjelezi meg.

Az örökkévalóság keresztény felfogásának kifordítására a leghangsúlyosabban az Aeternitas címü szövegegyüttes koncentrál. Aeternitas címmel négy írás szerepel a kötetben, amelyek közül az (1) és a (3), valamint a (2) és a (4) rímel egymásra témájában és az örökkévalóság fogalmának értelmezése tekintetében. Az örökkévalóság szemantikája két irányba mutat a két szövegpár alapján: az egyik szerint - paradox módon - az örökkévalóság a végesség képzetével [(1); (3)], a másik irány felöl pedig az örök kárhozattal állítódik párhuzamba [(2); (4)]. Az (1) szöveg a nyelv terében, nyelvi műveletek (hasonlítás) révén kapcsolja össze a végességet és az örökkévalóságot: „Az örökké-valóság / hideg, mint a véső, [...] merül, mint a kavics, [...] ugrik, mint a bolha, $[\ldots]$ mély, akár az elme, $[\ldots]$ ketyeg, mint az óra, $[\ldots]$ vékony, mint a penge, [...] rövid, mint az élet, / hirtelen ér véget, / mire elmeséled."4 Borbély előbb a merülés, a ketyegés, az ugrás tér- és időbeli haladást sugalló igéivel mozdítja ki az „örökké-valóság” fogalmának az állandósággal, mozdulatlansággal azonosítható jelentéskörét, majd a „mire elmeséled” zárlattal az „örökké”-nek a nyelvben való végességéről, a kimondás aktusának időbeli korlátairól szól. Ezért az „örökké-valóság” itt úgy jelenik meg, mint egyedül a nyelvben létező fogalom és képzet, ezért a nyelv természetéből fakadóan jelentése poliszémikussá válik.

\footnotetext{
${ }^{3}$ „A szekvenciában föllelhetjük azt az egymásra következéses, ismétlődő, temporális mozzanatot, amit de Man az allegória alapsajátságaként kimutatott. Liturgikus eredetű, közösségi formaként, mondhatni, a megvallottnak-dicséretnek állandóságát, az időn túlinak az időben való - szekvenciális - elhelyezkedését képes elmondani. A keresztény hitvallás alaptartalmait érő provokáció tehát e szerkezet által hangzik föl. [...] Ám Borbély [...] a személyes gyász számára olyan nyelvet választ, mely közössé formálja mind a Másik, mind a magunk halandóságának elhordozhatatlan terheit. [...] Az olvasás folyamatában nem csak a siratás és a memento mori közösségének részeseivé válhatunk, hanem láthatjuk, amint a személyes veszteség, fájdalom - az ismétlésen túl - fölnyílik arra, hogy az emberi szenvedésről, a halálnak kitett élet törékenységéről szóljon." Szücs Teri, A gyász képtelen képei (Borbély Szilárd: Halotti Pompa), Alföld, 2009/7, 96-98.

${ }^{4}$ A Halotti Pompából vett idézetek az alábbi kiadásból származnak: BorbéLy Szilárd, Halotti Pompa, Pozsony, Kalligram, 2006, 25.
} 
Az Aeternitas (3) szintén a végesség felől ragadja meg az „örökké valóságot”, amely a rablógyilkosság különböző mozzanataival válik egyenlővé, ugyancsak hasonlító szerkezetek által: „Az örökké valóság / olyan, mint a fejsze, / amellyel egy gyilkos / vert valakit fejbe. [...] Az örökké valóság / vörös, mint a friss / vér. Fölötte a pára. / Majd eloszlik az is. [...] Az örökké valóság / akár a gyilkosság, / széttöri a Képmást, / a Halottnak Arcát // Az örökké valóság / tökéletes, mint a / Tökéletes Büntény / megfejtetlen Titka. [...] Az örökké valóság / olyan, mint a Hajnal, / amelyre nem ébred / többé az Őrangyal." (50.) Az „örökké valóság” lesújtó fejszeként az egyszeriséget és visszavonhatatlanságot sugalmazza, elpárolgó páraként éppen az eltörlődésre (eloszlására, testi bomlásra), ha nem is a visszavonhatóságára, de az „örökké valóság” befejezhetőségére, végességére utal a hasonlítás-alakzat terében. Bár a „Képmásnak” - mely egyértelmüen az értelmezés körébe vonja az Isten-ember képmás viszonyt is -, a „Halott Arcának” széttörése egyértelműen referencializálható: több versben is hangsúlyossá válik az arcnak, koponyának szétzúzása, ami a szülőkkel történtek feldolgozásaként is érthető. Az „örökké valóság" a képmás széttörésével valaminek az eltörléseként értelmezhetö, mivel ugyanúgy megsemmisít és eltöröl, mint a gyilkosság. A tökéletesség és a változ(t)at(hatat)lanság aspektusa is megjelenik ugyan a versbeli „örökké valóság” minőségei között, de ez - mivel a Hajnalra többé nem ébredő őrangyal képe, illetve a „Tökéletes Büntény” titkához hasonlítás alakzata jeleníti meg - sokkal inkább a gyilkosság (meg)történésének állandó jelenlétét és visszavonhatatlanságát sugallja. A gyilkosság ezek szerint soha nem ér véget: amit eltörölni képes, az a „Képmás”, az Isten képmású emberi arc.

Fontos megjegyezni, hogy az örökkévalóság írásmódja folyamatosan változik a szövegekben. Az első vers a kötőjeles írásmódot, a harmadik a különírást választotta, és a jelenleg kiemelésre nem kerülő Aeternitas (2) és (4) az „örök zsidó” toposzát feldolgozó darabokban is eltérő írásmódot választ Borbély (előbbiben nagybetűvel, kötőjellel: „Örökké-valóság”; utóbbi esetében egybeírva nagybetűvel „Örökkévalóság”). Az eltérő írásmódok lehetséges jelentéseire nem térek ki, azonban az látható, hogy Borbély az örökkévalóság írásmódját aszerint is változtatja, hogy a végesség vagy az örök kárhozat felől közelíti meg azt (nagy és kis kezdőbetűk). Valamint jelentős az egybe és különírás jelentéshordozó potenciálja: ez talán az Aeternitas (3) el nem múló gyilkosságtapasztalatának, a meg nem oldott, lezáratlan ügy kapcsán külön írt „örökké valóság” esetében a legszembetünőbb.

A kötetben megjelenő élet és halál viszonya az örökkévalóság hagyományos értelmezésének eltörlésén is alapszik. Főként a feltámadás, az üdvözülés hiánya az, ami jobban érthetővé válik, amennyiben az örökkévalóság az egyik alkalommal a nyelvben kimondott véges fogalom, máskor az örök kárhozat és büntetés képzetéhez kapcsolódik (Aeternitas [4]), esetenként pedig a folytonosan jelen lévő gyilkossággal azonosítható. Ezen a ponton fóként azokra a szövegekre érdemes gondolni, amelyek a karácsony, a húsvét és a szülőket ért támadás egymásra írásával radikálisan átrendezi a keresztény vallási hagyományból örökölt dogmákat és képzeteket. Az állandó egymásra montírozás, a halál brutalitásának színrevitele, valamint a 21. századi szekularizált európai 
kultúra összehasonlítása a halálhoz egészen másképp viszonyuló keresztény hagyománnyal, azt eredményezi, hogy kérdésessé válik a feltámadás lehetősége. Az olyan verszárlatok, mint például „a Lélek csak gyufaszál; // ki gyújtja meg, ó Mária, / hol a kínban az a Szikra, / ha Krisztus is halott már?” (V., 31.), vagy „A Szörnyü Nap Rád bámulunk, / a Testre, kit szült Mária. / Nem mozdul, hallgat, nem bocsát, / és nem támad fel már soha." (VII., 36.), illetve „Az embert váltsa meg más, / mert nem lesz több Feltámadás." (Rosarium A Végsőről, 52.) azt mutatják, hogy Borbély Szilárd költészete nem számol a feltámadás és az üdvözülés lehetőségével. A szövegek egyfelől megmozgatják a keresztény vallási hagyomány szimbólumait, dogmáit és az erre épülő imahagyományt, másfelől viszont kifordítják és eltörlik a legfontosabbat, a húsvét eljövetelét.

A halál és az elmúlás fogalmainak kétséges helyiértéke, jelentéseiknek eldöntetlensége a kötetben magával hozza az énkonstrukció bizonytalanságát, feltárhatatlanságát is. A szövegek arról tanúskodnak, hogy az én, a szubjektum a nyelv és a test összjátékából adódik, ám, a kötetet olvasva, ennek az összjátéknak a viszonyrendszere nem írható le egyértelmủen. Az alapvető kérdés a halállal hozható összefüggésbe: ki (lélek, gondolat, tettek?) vagy mi (test, nyelv?) pusztul el, szünik meg a halált követően. Borbély kötetében az ember mint testének, nyelvének és gondolatainak összessége kerül középpontba és maga az emberi lét válik kérdésessé, a szubjektum, az identitás alkotóelemei kérdőjeleződnek meg. Úgy tünik, hogy az én leírása, megragadása lehetetlen vállalkozás, állandó mozgás figyelhető meg a szövegekben: a test, a nyelv, a gondolat vagy a lélek viszonyrendszere rögzíthetetlennek látszik. Nem egyértelmü, hogy a kötetben a nyelv felöl értelmezhetö-e a test, vagy a test felöl a nyelv, ám nem is bizonyos, hogy ezt a kérdést el akarják dönteni a versek. Noha az egész kötetet áthatja ez a probléma, leginkább az Ámor \& Psziché-, valamint a Haszid Szekvenciák-ciklusokban találhatók olyan szövegek, amelyek ezt a viszonyrendszert járják körül, mindig más nézőpontból és más hangsúlyokkal. Ezt az állandó nézőpont-eltolódást, ugyanakkor bizonyos pontokon egybehangzóságot az Ámor \& Psziché-ciklusból három olyan vers felvillantásával szeretném bemutatni, amelyek a nyelv, a test és az én hármasát hangsúlyozzák.

Az első kiemelendő szöveg az Ámor \& Psziché-ciklus második verse, $A z$ anyagtalan magzat, amely a személyiség kialakulásának és a nyelvnek egymásra hatását állítja középpontba mint én-alakotó viszonyt, miközben a test e kölcsönösségnek inkább háttereként, anyagaként szolgál és nem válik egyenlővé az énnel. A teljes szöveget idézem: „Az emberi arc közel kétszáz érzelmi / állapotot képes mimikával kifejezni. / A csecsemö ugyanennyi hangot tud / adni. A beszédhez azonban csak néhány // tucatra van szüksége. A többit elfelejti. / A gyermek nem nyelvi szabályokat tanul, / hanem téves példákat hall. A hibákból / helyes szabályokra következtet. Majd // személyisége is a nyelv által alakul ki. Ezért / van, hogy az én nem ég el a krematóriumban, / ahol hamvasztás előtt a márványlapra // helyezett test nagy inait átvágják, a koponyát, / hogy föl ne robbanjon, meglékelik. A comb / forgócsontjait végül mégis meg kell őrölni." (78.) A beszéd, a nyelv itt úgy tünik fel, mint ami a test lehetőségeit korlátozza, a nyelv - a szabályok és konvenciók, a grammatika révén - meghatározott mederbe terelve be- 
széddé alakítja a hangadást, és ennek következtében a kezdetben formátlan, ám annál sokszínűbb hangokat és jeleket feleslegesnek és feledésre ítéli. Fontos felhívni a figyelmet a kötetben egyébként rendszerint rapszodikusnak tünő sortörésekre, amelyek által az értelmi egységek határai is áthelyeződnek. Míg a vers szemantikai szinten a nyelvet szabályozottnak, szigorú rendkövetőnek állítja be, mely erőszakot tesz a test szabály nélkülinek látszó ösztönösségén, addig a szöveg strófaszerkesztése rendezetlenségeket mutat és a szabálytalant viszi színre. A nyelvnek itt megjelenített erőszakossága a kötet több szövegében is megjelenik, például Ámor figurájában, aki az éjszaka leple alatt teszi magáévá Pszichét. A nyelv erőszaktevő egyfelől, másfelől azonban a személyiség alakítója is. A nyelv által kialakult személyiséget azonban Borbély, úgy tűnik, valamiképpen a testen kívülre helyezi: „az én nem ég el a krematóriumban”. (78.)

Az énkonstrukció , anyagtalansága” és ezáltal hozzáférhetetlensége is megjelenik ezáltal, ugyanakkor más szöveghelyek éppen arról tanúskodnak, hogy a test mégis valamiképpen magába zárja az ént: a Testben élni címü szöveg is példa erre. Ez az írás abban a tekintetben némileg folytatja az előzőleg kiemelt vers gondolatmenetét, hogy a nyelv itt is átlépi a test, a testi létezés határoltságát: „[...] Ugyanis a tárgyi világgal párhuzamosan / a tudat képes megjeleníteni a dolgokat // mentális reprezentációk által. [...] A nyelv a reprezentáció / harmadik síkja. Segítségével egy másik / tudatban is jelenlévővé tehető a tárgy // képe. [...] És ha a szeretők éjjel // találkoznak, a sötétben lelkük érintkezik. / A létezésnek ugyanis van egy magasabb / szintje. Mert testben élni maga a halál." (82.) Ahogy az előző szövegben a test, a testben lét itt is az elpusztíthatóval, az elmúlóval azonosítható: ugyanakkor a nyelv (mentális reprezentációk, metaforák stb.) közbejöttével rajta kívüliként jelenik meg, illetve a „létezés magasabb szintje”-ként feltünik a lélek fogalma is .

Borbély Szilárd verseiben a lélek nem feltétlenül jelent többet a nem megfoghatónál, miközben azt is érdemes leszögezni, hogy Psziché, aki hagyományosan a lélek megszemélyesítője, Borbélynál gyakran a test metaforája, míg Âmor sok esetben inkább a nyelv működésmódjával, a nyelvvel mint erőszaktevővel azonosítható. A hangok emblémájában ez a metaforikus azonosítás jól látható: „A nyelv a legkegyetlenebb. Nem emberi. / Csupán jelek játéka és szabályok hideg / rendje. Egyetlen ember sem tulajdonosa / a nyelvnek, amit beszél, hanem kölcsön // kapta. Amikor beszél, úgy látogat el hozzá / és szállja meg a Hang a testét, ez a kegyetlen / Isten, ahogy Ámor tette Pszichével. Amíg / beszél, addig sem ö beszél, hanem az // istenek." (100.) A nyelv és a hang mint „megszálló" rendszer mintha médiumként használná a testet, ennek a versrészletnek fényében a test szolgáltatja a közeget míg a hang, az istenséghez kötöttsége által, egyfajta immateriális képződményként képzelhető el, amely uralja a testet. Kegyetlensége éppen abból fakad, hogy nem lehet elsajátítani, sőt használni sem, hiszen éppen a nyelv használja fel a test közegét a megnyilatkozásra. A fent idézett három szövegből látható, hogy a nyelv minden esetben valami külső, az énbe nem saját rendszerként illeszkedik, hanem mint kölcsönkapott jelrendszer, mely bár használható és a személyiséget is ala- 
kító tényező, de birtokba nem vehető, sőt, úgy látszik, éppen a nyelv sajátítja ki a testet: „megszállja”. Noha a szövegekben megjelenik a lélek fogalma is, az mégsem válik egyértelmüvé, hogy a test-nyelv relációban hol helyezkedne el és milyen viszonyban állhat az énnel. A három tényező feszültsége ugyanakkor jól érzékelhető a fenti példákból. A Haszid Szekvenciákban megjelenő énkonstrukciókat további vizsgálat alá lehetne vonni, ám A Testhez szövegei talán jobban közelíthetöek az Ámor \& Psziché-szekvenciák verseihez.

\section{Test, trauma és önelbeszélések}

Noha Borbély Szilárd $A$ Testhez kötetben egészen más vállalkozásba fogott, a kritikai visszhang nagyrészt mégis a Halotti Pompa folytatásának tekintette. Ennek oka leginkább abban keresendő, hogy az alcím által is meghatározott Ódák \& Legendák kettősében az ódák hasonló kérdéseket vetnek fel, mint a Halotti Pompa test és nyelv viszonyát érintő szövegei. Az ódák megszólítanak egyes testrészeket, a test egészét felépítő szöveteket, formákat, de ugyanakkor nyelvi elemeket, illetve fogalmakat is aposztrofálnak. Annak a test és nyelv közötti viszonynak a kibontása, amely megkezdődött a Halotti Pompa szövegeiben, mintha csakugyan folytatódna az ódákban: a test megjelenik akadályként, hordozóként, csomagolásként (A Burkolathoz) vagy a jelek tereként („A testem csupán költött // alak, amelyben vándorol / a Jelek jelentése." Az Alakhoz). ${ }^{5}$ Jelen dolgozatban az „ódák” csoportjához sorolható három szöveget, valamint egy „legendát" emelek ki, amelyek által a kötet múködésmódját, a Halotti Pompával való kapcsolatát és a trauma-fogalom felől megközelíthető énkonstrukciót igyekszem megmutatni.

$\mathrm{Az}$ a test-nyelv viszony, amely a Halotti Pompa szekvenciáiban már körvonalazódott, továbbíródik az ódákban, ami jól látható például a 8 . A Testekről összefoglaló cím alatt álló második versben, a $8.2 \mathrm{~A}$ Megfosztásban, amely a születés pillanatát veszteségként és erőszakként jeleníti meg. ${ }^{6}$ A születésben a test „lelketlen állatiasságát”, „részvéttelen brutalitását” hangsúlyozza ez a darab: „A nyálkában, a verítékben, az ordítás embertelen / hentesmunka rituáléjában van // az élet és halál közvetíthetetlen / pillanata [...]”. (30.) A test nyerseségével, a brutalitással azonban úgy tünik, hogy a nyelvünk, kultúránk nem tud mit kezdeni, épp ezért „Az apajogú nyelv fogalmai logoszról, // fényről, áhítatról, szűzről, a zavaró / világot elkendőző szavakról szólnak." (30.) Látható az idézettekből, hogy ebben a versben a test valóságának nyelvvel való elkendőzése, a nyelv test feletti uralma, a test nyelv általi határok közé szorítása hasonlóan ábrázolódik, mint a Halotti Pompában az Ámor és Psziché viszonya által

\footnotetext{
${ }^{5}$ Az idézetek az alábbi kiadásból származnak: BorbéLy Szilárd, A Testhez: Ódák \& Legendák, Pozsony, Kalligram, 2010, 22.

${ }^{6}$ A 8. számú szövegegyüttes azért is érdekes, mert ez nem szólítja meg tárgyát, nem testekhez, hanem testekről szól, így nem is feltétlenül tekinthető ódának, ugyanakkor a női perszónák által elbeszélt legendáknak nevezett szövegek eljárásait sem követi.
} 
leírt, férfi attribútumokkal rendelkező nyelv erőszakossága a Pszichével azonosított test felett. A kötetben a női test a társadalom, az „apajogú nyelv” kitettjének, sokszor áldozatának tünik fel. Az anya teste, a magzatot hordozó és elvesztő test, a közös test megképződésének és elvesztésének folyamata a szöveg végén az isteni teremtés folyamatához lesz hasonlatos, majd az isten nélküli - a közös testtől megfosztott, az istentől megfosztott - test létével zárul a szöveg: „Aztán a test története, majd az // elszakadás az anyával közös / testtől, aki a születéskor halt meg, / mint az Isten. Elválni az anyától / a testtelen halál gondolatának / belátása. Tudni, hogy nincs szeretet, csak / a testben a vér, a könny, az istentelen." (31.)

Máshogy értelmezhető ez a viszony a 37.1 De Sade lilioma és a 53.1 De Sade rózsája címü szövegekben, amelyek inkább a test és a nyelv egymásra utaltságát, elválaszthatatlanságát jelzik. A kötet egyik értelmezője kiemelte, hogy A Testhezben különböző tartalmai vannak a kis betüvel és nagybetüvel írott testnek: a kis betüs testhez jobban tapad a test anyagisága (,a kisbetűs test a vágyak kegyetlenségében mutatkozik meg”), míg a nagy betüvel írt inkább a transzcendens felé hajló, lélekkel telített. ${ }^{7}$ Innen válna érthetővé, hogy a libertinizmussal összekapcsolt de Sade miért jelenik meg a kisbetűs testhez írott ódák alcímében - a test „léleknélküliségéről van szó, [arról,] hogy puszta gépezet, részint pedig hatalmi viszonyok kérdéséről". ${ }^{\mathrm{A}} \mathrm{A}$ hatalmi viszonyok a beszédben és az áldozat-gyilkos dualizmusában jelennek meg, amennyiben a gyilkoshoz társul az uralkodó beszéd, míg a némaság az áldozat attribútuma lesz, így a hallgatás az alárendeltséggel párosul. ${ }^{9}$ A De Sade liliomában a nyelv, eltérően a Halotti Pompa szövegeiben megjelenő elképzeléstől, nemcsak elvont jelrendszerként, hanem mint a testből, húsból létrejött, a hangszalagok által kipréselt fizikai létező hang jelenítődik meg: „a húsból sajtolt hangok / a hangszalag két kötegét / a gégefóből hallod // ahogy rezeg a levegő / a nyálkás hús csinálja, / ahogy hangokat csal elő / a testnek rothadása // a szavakat is kitörli”. (112-113.) Egyfelől a nyelv a testre utaltként, mint a hangképző szervektől függő képződmény jelenik meg, másfelől azonban a szöveg a testet is grammatikai jelenségként értelmezi: „A testek csak grammatikák, / a tér leképezése, / s a nyelv a látható világ, / a látás a tér része, // a koponyaformába zárt / agyszövet belső körét / a Gondolat úgy járja át, / hogy elgondolja önként // a nyelvet, mint a létezést, / amely a test beszéde [...]”. (112.)

E két részletből látható a test és a nyelv egymásra utaltsága, hiszen a nyelv hangként - a testből biológiai és fizikai folyamatok révén - szólal meg, itt már nem egy testet megszálló nyelvrendszerről, vagy egy immateriális hang képzetéről olvashatunk, mint ahogy az korábban Halotti Pompa A hangok emblémája című szövegében megjelent. A test mint grammatika és a nyelv mint a test beszéde elválaszthatatlan egységben jelenik meg, önmagát elbeszélő, önmagát önmagából létrehozó és a pusztulás felé haladó

\footnotetext{
${ }^{7}$ JAKAB Villő-Hanga, „Test a testnek otthona”: Borbély Szilárd verseinek testképzeteiröl, Korunk, 2011/7, 90.

${ }^{8}$ Uo., 91 .

${ }^{9}$ Uo., $91-92$.
} 
gépként: „e furcsa gép csak tettetés / és pusztulás a léte // és nyelve mindig önbeszéd”. (112.) Ez az egymásra utaltság és oda-vissza ható viszony azonban a De Sade rózsája címü szövegben már sokkal inkább egyirányúnak tünik, amennyiben inkább ez a testet teszi meg a szöveg tárgyául és azt a nyelv rendszeréhez hasonlóként igyekszik megjeleníteni: „A Test csupán csak Gondolat, / szavak pozitúrája / jelek, ragok ruhája. [...] // A test csupán csak váladék / forrása, könnyü háló: / a nyál, a vér a sperma / kód, csupán csak jel: elszálló. / A kínra szomjan váró / jelzők hangalakja. // [...] s a vér is szó csupán csak?" (149.) Jelekre, ragokra, kódokra és hangalakokra bomlik a test, a gondolat és a szó szintjére vonja vissza Borbély az előbbiekben még nagyon is anyagiságában megjelenő, a pusztulásnak kitett testet. ${ }^{10} \mathrm{E}$ szöveg értelmezhető a test metaforákkal való leírásának kísérleteként (ahogy a ragok, jelek is kódot és információt hordoznak, azonképpen teszi ezt a nyál, vér vagy a sperma), ugyanakkor annak kijelentése, hogy a test „csupán csak Gondolat”, mintha azt feltételezné, hogy a testet kizárólag a nyelvi és gondolati rendszerek teszik elgondolhatóvá, ezek nélkül nem is létezik.

Ahogy a fenti szövegrészletekből látható, Borbély $A$ Testhez verseiben a test és a nyelv szoros összekapcsoltságát, egymással való leírhatóságukat és egymásra utaltságukat járja körül. A kötet terében megjelenő női traumatapasztalatokat elbeszélő legendák is a nyelv és a test összekapcsolódását viszik színre, hiszen a legendák szövegei magukon viselik a test traumáinak nyomait. A legendák szerepe az, hogy testek történeteiről és traumáiról tanúskodjanak: nyelvileg töredezettek, helytelen raghasználatok és ragelhagyások, kihagyások, szórendi felcserélések jellemzik ezeket, tehát a sérült test és psziché lenyomataként áll elö a sérült nyelvezet. A legendák közt találhatóak olyan szövegek, amelyek a szülést, a spontán vetélést, valamint az abortuszt tematizálják, de hangot kapnak a szexuális erőszak, az egyedül maradás, a holokauszt tapasztalatai is.

A női hangok a saját identitásukban meghatározó élményt, eseményt tárnak fel, olykor pedig egy-egy teljes élettörténetet is olvashatunk. Az egységes önelbeszélés lehetőségének kérdése még azon esetekben is felmerül, amikor narratív önéletrajzokról beszélünk. Nem csak az önéletírás elméletei kételkednek abban, hogy az egységes én elbeszélhetö, a szubjektum egységébe vetett hit már Nietzsche óta megkérdőjeleződik. A narratív identitás egységesítő szándéka és az ebben képződő hézagok szinte minden önéletrajz elemzési tárgyát képezhetnék. ${ }^{11}$

Az önelbeszélések fiktív, traumatizált női perszónák hangján szólalnak meg Borbély kötetében is, ami fokozza a töredezettséget, a hiányok megképződését, és tovább nehezíti az egységes identitásalkotás és az önelbeszélés lehetőségét. Fontos kiemelni, hogy a szövegek valódi önelbeszélések átdolgozásai, amelyek forrása két antológia: a Singer Magdolna által szerkesztett Asszonyok álmában síró babák, valamint a Pécsi

\footnotetext{
${ }^{10}$ Nemcsak állítások, hanem kérdőmondatok is szerepelnek a szövegben, így a test és grammatika összevonása bizonyos pontokon inkább felvetésként, kérdésként áll az olvasó elött.

${ }^{11}$ Friedrich Nietzsche, A hatalom akarása, ford. RoмнÁnyi Töröк Gábor, Bp., Cartaphilus, 2002, 219, 222. (485, 490-es töredék)
} 
Katalin szerkesztésében megjelent Sós kávé. Borbély ebből a két gyüjteményből emelte át a történeteket, de azokat jelentősen átdolgozta, nyelvileg sürítette, töredezettebbé tette, sok kihagyással élt, megbontotta a narratívát, időrendi cseréket hajtott végre. Ezzel együtt azonban megörizte a női hangokat („nem a nőkről szólnak ezek a müvek [...], hanem maguk a nők szólalnak meg bennünk"12), ám a versbeszéd, a ritmus töredezettsége azt a kérdést is felveti, mennyire tekinthetők e szövegek költői szövegnek, hiszen versritmus és „emberi vallomás töredezettségének határán” állnak. ${ }^{13}$ Bár Borbély meghagyja az egyes szám első személyü megszólásmódot, a szövegek megtépázottsága miatt kérdéses, mennyire tekinthető személyesnek a létrehozott megszólalásmód. Ez a nyelv ugyanis elfedi valamelyest az eseményeket, s nem a „szenvedések bírnak központi szereppel, hanem a grammatikailag redukált nyelven keresztül az elbeszélhetőség problémája”. ${ }^{14}$ Borbély költői eljárása tehát felerősíti a traumák nyomait a szövegekben, a nyelv sebzettségében színre viszi a nyelv és test kapcsolatát. ${ }^{15}$

Ez az eljárás megerősíthetőnek látszik a traumaelméletek felől , melyek mindegyre az emlékezetkiesést vagy a trauma elbeszélésnek nyelvi nehézségeit emelik ki. Többek között Leigh Gilmore mutat rá arra, hogy az önéletrajzi könyvek kiadása az 1940-es évektől kezdve folyamatosan növekedett, ami a történelmi traumatapasztalatokkal magyarázható. Ám ezeknek a feldolgozása új kérdéseket vetett fel: olyan nehézségeket, amelyekkel szembe találjuk magunkat, ha a trauma nyelvi megformálásával próbálkozunk, vagy azt értelmezzük. A nyelvnek önmagában nagy szerepe van abban, amit traumatapasztalatnak nevezünk. A trauma görög eredetü szó, melynek jelentése (seb, sérülés) eleve arra a sérülése mutat rá, amely a testen, a pszichében vagy a nyelvben is létrejöhet egy esemény által. Leigh Gilmore a beszéd lehetőségének és céljának kérdését felvetve azt hangsúlyozta, hogy a beszéd szükséges a fájdalom transzformálásához, ugyanakkor mindig kockázattal is jár. ${ }^{16}$ Ekképpen merül fel a figuratív nyelv mint a traumatapasztalatot hitelesen közvetíteni képes közlésmód, ám ennek megítélésében nincs konszenzus a szakirodalomban. Gilmore Lawrence Langerre hivatkozik, aki tagadja a trauma irodalmi nyelven belüli feldolgozásának lehetőségét. Langer szerint el kell szakítani a mindenkori trauma-elbeszéléseket a figuratív nyelvtől, míg Cathy Caruth épphogy az ellenkezőjét állítja ennek. A trauma sokszor olyan intenzív élmények átélését jelentheti, hogy elszenvedője sokszor el is felejtheti a történteket,

\footnotetext{
${ }^{12}$ ZsAdÁNYi Edit, „Hogyha eljár a szám”: Női élettörténet Borbély Szilárd verseiben, Parnasszus, 2009/4, 17.

${ }^{13}$ Uo., 19.

${ }^{14}$ JAKAB, i. m., 92.

${ }^{15}$ Valastyán Tamás a fenomenológia szempontjai felől közelítve úgy értelmezi, hogy e kötetben maga a test jut nyelvhez, a test kap hangot, ő beszéli el saját történetét. A szemeteskosár vers alapján kifejtve: „Mindehhez a testet kell megszólaltatni. Ezért teszi a testet a költő a lírai én prosopopeiájává. [...] maga a test történő beszéde válik tapasztalattá." Valastyán Tamás, Eredendö kiazmusok: A test mint a köztes világ fenoménje Borbély Szilárd költészetében, Alföld, 2014/8, 95.

${ }^{16}$ Leigh Gilmore, Limit-cases: Trauma, self-representation, and the jurisdiction of identity = Autobiography IV., ed. Trev Lynn Broughton, London, Routledge, 2007, 232-233.
} 
ám ha az emlékek visszatérnek, gyakran nagy nehézségekbe ütközik áthelyezésük a verbalitásba. ${ }^{17}$ Éppen ezekben a helyzetekben segíthet a figuratív nyelv, amely valami olyasmit képes feltárni, amelyre a diszkurzív nyelv képtelen. ${ }^{18} \mathrm{~A}$ figuratív nyelv használata mellett érvel Nora Strejilevich is, amikor a különböző borzalmakra emlékező tanúk nyelvét elemezve arról beszél, hogy a precizitást követelö bíróságokon elvárják a traumát átélt személyektől, hogy pontosak legyenek, holott, a trauma nyelvének megfelelően, ezen tanúvallomásokban az összefüggéstelenségeknek, csöndeknek, töréseknek, kihagyásoknak is helyet kéne adni, tehát a traumáról való tanúskodás nyelvének irodalminak kellene lennie. ${ }^{19}$ Ugyanakkor nem minden traumaelmélet van meggyőződve arról, hogy a trauma következtében felejtés lép fel. Joshua Pederson ennek éppen ellenkezőjét állítja; úgy véli, hogy a traumát átélt személyek legtöbb esetben emlékeznek a velük történtekre, és el is tudják beszélni akár részletekbe menően az eseményeket. Az érzékelés mikéntje azonban mintha megváltozna ezekben a helyzetekben: az elbeszélők lelassult időről vagy éppen valótlannak tűnő tapasztalatokról számolnak be. ${ }^{20}$ Ám még akkor is, ha egyetértünk a Pederson által mondottakkal, és elfogadjuk, hogy a trauma nem feltétlenül okoz emlékezetkiesést vagy elfojtást, azt még akkor sem lehet tagadni, hogy a trauma-elbeszélés mindenképpen okoz valami zavart vagy nehézséget a nyelvi megformálásban. Épp ezért lehet még nagyobb jelentősége a figuratív nyelvnek a traumatapasztalatok leírása során. Nora Strejilevich például, aki megírta saját vallomásos regényét az argentínai „Piszkos Háborúról”, azt mondja, hogy az irodalmi vallomásoknak az a fó hozadékuk, hogy biztosítják az eltávolítás lehetőségét. Az emléknyomokat narratívába lehet rendezni és jelentéssel lehet őket felruházni, ám ezzel együtt a hangsúly magán a nyelven marad, ami gyakran fragmentált és töredezett, de épp ezáltal tudja bemutatni az összeomlott identitást, egy közösségnek vagy társadalmi rendszernek a széthullását. Az elbeszélés során te-

\footnotetext{
${ }^{17}$ Egyes feltételezések és traumaelméleti irányok szerint azokat a tapasztalatokat, amelyeket a nyelv nem tudott artikulálni, annak megörzésére képes a test. Vö. Allison Crawford, 'If the Body Keeps the Score': Mapping the Dissociated Body in Trauma Narrative, Intervention and Theory, University of Toronto Quarterly, 2010/2, 702-719.

${ }^{18}$ „Caruth szerint a trauma egy olyannyira intenzíven fájdalmas tapasztalat, hogy az elme képtelen azt normális módon feldolgozni. A közvetlen utóhatás során az áldozat teljesen el is felejtheti az eseményt. És ha a traumáról visszatérnek az emlékek, ezek gyakran nem nyelviek és előfordulhat, hogy az áldozat képtelen szavakkal leírni őket. Caruth mégis fenntartja, hogy az imaginatív irodalom - vagy a figurális nyelv, s nem a szó szerinti - el tudja »beszélni« a traumát, amikor a megszokott, diszkurzív nyelv csődöt mond, és így a fikció segít hangot adni a traumatizált személyeknek és közösségeknek.” Ennélfogva Crauth traumaelmélete erős javaslatot tesz arra, hogy az irodalom tanúságtevő erejét hangsúlyozzuk. Joshua Pederson, Speak, Trauma: Toward a Revised Understanding of Literary Trauma Theory, Narrative, 2014/3, 334. (Amennyiben külön nem jelzem, az idegen nyelvü szakirodalmi idézeteket a saját fordításomban közlöm. - G. E.)

${ }^{19}$ Nora Strejlievich, Testimony: Beyond the Language of Truth, Human Rights Quarterly, 2006/3, 710. ${ }^{20}$ „Azok az emberek, akiknek húsbavágóan közeli tapasztalatuk volt a halállal (ilyen lehet egy hegyről lezuhanni) gyakran számolnak be a tudat szélsőséges, disszociatív változásairól (lelassuló idő, minden valótlannak tűnik), miközben teljes mértékben képesek maradnak arra, hogy részletes leírásokkal szolgáljanak tapasztalataikról." Pederson, i. m., 338.
} 
hát egy sajátos nyelv teremtődik, amely a traumatikus esemény valódi természetét mutatja meg. ${ }^{21}$ Fontos lehet még a trauma-elbeszélés szempontjából Dori Laub tézise, miszerint a trauma meg sem történt egészen addig, amíg el nem beszélték; mindig szükség van egy együttérző hallgatóra, aki számára artikulálni lehet a traumatapasztalatot, ami azért szükséges, hogy az esemény valójában megtörténjen. ${ }^{22}$

A Testhez című kötet női perszónák által elmesélt történeteiben valami hasonló történik a nyelvvel, mint amit a bemutatott traumaelméletek leírnak. Herczeg Ákos kritikája szerint ezekben a legendákban a női test áldozatként jelenik meg, ha pedig a legenda müfajt (mint szentekről szóló történetet) is figyelembe vesszük, úgy azt mondhatjuk, hogy ezek a nők a szentekéhez hasonló helyzetbe kerülnek. ${ }^{23}$ Ám a szent többnyire tudatosan vállalja a szenvedést, Borbély viszont inkább társadalmi elvárások és normák kitettjeként, bizonyos esetekben pedig férfiak áldozataként ábrázolja a női sorsot és testet. ${ }^{24} \mathrm{~A}$ női test társadalmi kitettsége és az a nyelv, amelyet ennek leírásához használ, feszültségben áll egymással, tekintve, hogy a nyelv ugyanannak az erőszakot elkövető társadalomnak a képződménye. A nyelvnek a kettős, egyszerre személyes és társadalmi, kollektív ${ }^{25}$ természete kifejezetten hangsúlyos, hiszen a nyelv konvenciókra épülő kódjait kell müködtetni olyan tapasztalatok közvetítéséhez is, amelyek nem illeszthetők a társadalmilag konvencionálisan leírható tapasztalatok sorába. A nyelv a Halotti Pompában a testen erőszakot tevő hideg rendszerként jelenítődött meg. A Testhez címü kötetben viszont a nyelv mint rendszer összeomlik, mintha nem lenne képes uralni a kifejezést; a nyelv a testtel szorosabb összeköttetésben áll, szinte performatívumként jelenik meg a legendákban.

A legendák közül egy holokauszttraumát feldolgozó szöveget (A matyóhímzés ${ }^{26}$ ) emelek ki példaként, amelyet a szerző Sommer Magda Állomások címü szövegét felhasználva dolgozott fel. A novella kronológiai rendben beszéli el az elbeszélő gyermekkorában történteket a numerus clausus bevezetésétől addig a napig, amikor Auschwitzba érkezett. Borbély szövege ezzel szemben felerösíti a traumatikus nyelvet azáltal, hogy bizonyos pontokon megtöri a kronológiai rendet, s mint a korábban idézett szövegekben, itt is rontott nyelvet alkalmaz; egyszersmind a vers elejére helyez egy emfatikus pillanatot: a lírai én orvos-apja fecskendőket tesz ki a matyóhímzéses terítőre, és azt ajánlja a családnak, hogy kövessenek el kollektív öngyilkosságot, mielőtt elhurcolják

\footnotetext{
${ }^{21}$ Strejllevich, i. m., 710-711.

${ }^{22}$ Gilmore, i. m., 233.

${ }^{23}$ Herczeg Ákos, A test grammatikája, Alföld, 2011/9, 102-105.

${ }^{24}$ Vö. GYöre Bori, A női test transzcendenciája, Múlt és Jövő, 2014/1, 65-71.

${ }^{25}$ A vallomásos költészetben a nyelv személyes és személytelen aspektusa kapcsán lásd William MATTHEws, Personal and Impersonal = After Confession: Poetry as Autobiography, eds. Kate Sontag, David Graham, Graywolf Press, 2001.

${ }^{26}$ Ezen a ponton kiemelhető Zsadányi Edit azon megállapítása, miszerint Borbély metonimikus címeket ad, amelyek látszólag lényegtelen elemeket emelnek ki, ellentétben az összefoglaló jellegü címadással. ZsADÁNYI, i. m., 22.
} 
őket. Ám a lány nem egyezik bele. A matyóhímzésnek mint a magyar kulturális identitás egyik meghatározó szimbólumának és a halálos mérget tartalmazó fecskendőknek a találkozása egy zsidó család asztalán értelmezhető szimbolikusan: úgy, mint a magyar kultúrától való végső elszakadás pillanata, az a pillanat, amikor visszavonhatatlanul megtörik a kultúrához füző viszony. Egy olyan viszony, amely pedig a vers alapján igen erös és fontos volt korábban (például a kislány Magyarország feltámadásáért könyörög esti imáiban).

Az elszakadás folyamatát jól ábrázolja előbb a numerus clausus bevezetése, majd az, hogy a lírai ént leültetik az iskolában a himnusz éneklése alatt - ennek a folyamatnak a vége az Auschwitzba érkezés. A versben gyakran él a lírai beszélő az eltávolítás eszközével is, egyrészt saját magától (mint alanytól) távolít az olyan szófordulatok használatával, mint „az én eszem nem értette” (ahelyett, hogy nem értettem), amikor pedig a borzalmak felsorolásába kezd, elhagyja a cselekvő alanyt, amennyiben a szörnyüségek válnak alannyá és eképpen végrehajtó aktív perszóna nélkül érkeznek: „és jöttek a szörnyüségek sorba”. A szövegnek azonban azon a pontján a legerősebb a nyelv roncsolása, amikor az Auschwitzba érkezésről kapunk leírást; rövid mondatok, kiszakított helyzetképek, fragmentáció, grammatikai hiányok jellemzik a vers utolsó néhány sorát: „Egy német tiszt terpeszbe. Állt valahol / ott messze. Minket jobbra irányít. Vetkőzni kellett / egy terembe. Aztán áttereltek egy másikba, és a vasajtót / rácsapták reteszre. Ordítva dörömböltem egyre. Valóban / elvesztünk, értettem meg végre... Visszafordulva többiek / már kopaszra nyírva. Meg sem ismertem senkit. / Álltak ott, mint a birka. Testükre libabőr volt írva." (21.) Látható, hogy nemcsak a töredezettség, illetve a grammatikai hibák szintjén mutatkozik meg a nyelv sebzettsége, hanem ezen a ponton már a jelen és múlt idő is egymásba mosódik, valamint a térbeli „itt”/„ott” szembenállása is megkérdőjeleződik, hiszen a német tiszt múlt időben „ott állt”, de ugyanakkor a jelenben, itt „irányít”. A vers zárlatában megjelenő libabőr képzete - amely egyfelől kézenfekvő módon érthető a meztelenség, félelem és megalázottság testi reakciójaként, egyúttal felidézheti a vers elején megjelenő hímzést, főleg az „írás” szó használata miatt, tekintve, hogy a kézimunka néhány fajtáját (az előre megrajzolt motívumok hímzését) írásként is szokás nevezni. Így a hímzés motívuma - amelyhez elválaszthatatlanul hozzátartozik a rajta fekvő fecskendők fenyegetése - végül a kitettség, a másoknak való kiszolgáltatottság és megalázottság testre írt jeleivé alakul át, amelyeket végül a nyelven keresztül a szövegtest is felmutat.

Dolgozatomban igyekeztem rámutatni arra, hogyan alakul Borbély Szilárd két verseskötetében a test és a nyelv kapcsolatának leírása, milyen poétikai eljárásokkal él e viszony kibontása során, valamint milyen következményei vannak ennek az elgondolásnak, ha a traumatapasztalatok színreviteléről van szó. Míg a Halotti Pompa esetében a személyes hang visszavonása, a személyes élmény általánosabb kérdésekbe való transzformálása történik a kötet által megmozgatott három nagy hagyományon keresztül, addig $A$ Testhezben már nemcsak a viszony leírása jelenik meg a szövegekben, hanem a test és nyelv elválaszthatatlanságának színrevitele is a traumatapasztalatok elbeszélé- 
seinek segítségével. Fontos kiemelni, hogy a személytelen hang megképzése éppen a személyes történetet (szülők megtámadása) érintette, míg az átvett és átdolgozott traumatörténetek jobban megőrizték a személyes hangvételt. A testet és a nyelvet érintő kérdések minduntalan felvetették az én helyének kérdését is (mint a nyelv és az én, a nyelv és az identitás kapcsolata, a személyiség alakulása a nyelv által gyakran felmerült a versekben), ugyanakkor $A$ Testhez legendái azt is megmutatták, hogyan teheti tönkre a nyelvet egy trauma által kizökkentett identitás. Ahogy a női hangok által elbeszélt történetekben a testekre a trauma okozta sérülések jelei íródnak, úgy Borbély Szilárd kötetének szövegtestein is kimutathatóvá válnak, performatíve megjelennek a nyelv sebei.

\section{EszTer GoROve}

Body, language, and the construction of the self in Szilárd Borbély's poetry Szilárd Borbély's poetry often operates with the concepts of body and language, especially regarding trauma experiences and mourning. My paper examines these concepts in two of his volumes (Halotti Pompa [The Splendours of Death] and A Testhez [To the Body]) and tries to show how the relation of body and language creates the notion of the self. The meanings of these notions constantly change and are extremely volatile in Borbély's poetry, therefore I attempt to highlight how they occur through some examples rather than giving a dictionary. At the same time the paper aims at presenting the main characteristics of Borbély's poetry and showing how these poems transform the innermost personal experiences to more general (social and cultural) problems. Interpreting the "legends" of A Testhez, my paper also introduces relevant theories of trauma, and focuses on the relations between trauma experiences and fragmented language, and on the poetic tools that make the "wounds" of the texts visible. 